\title{
Apresentação
}

Os textos deste número da "Revista Acolhendo a Alfabetização nos Países de Língua Portuguesa" - Moçambrás- apesar da diversidade geográfica da sua proveniência (África, Américas e Europa), e, conseqüentemente, da diversidade cultural e das práticas pedagógicas, mostram que os diversos quadrantes do mundo caminham na mesma direção: a da edificação de uma sociedade informada, inclusiva e responsável. Uma sociedade em que se valoriza o Homem como agente transformador do mundo em que vive independentemente da sua condição social. A valorização do Homem passa necessariamente pela sua educação/formação, quer em contextos formais (por exemplo, a escola), quer em contextos informais (por exemplo, a comunidade de que faz parte ou mesmo a família).

Uma leitura atenta dos textos deste número deixa perceber a premência de uma educação eficaz que habilite o Homem à mobilidade e à flexibilidade socialmente impostas pela globalização capitalista. Para tal, é imperioso que as práticas de alfabetização não se restrinjam apenas à aquisição das habilidades de leitura e escrita. É necessário que essas práticas sejam socialmente situadas, isto é, que estejam firmadas no contexto ideológico e cultural em que têm lugar, constituindo-se como exercício efetivo e competente da tecnologia da escrita, possibilitando às pessoas a capacidade de ler e escrever para atingir a diferentes objectivos.

Contudo, tais práticas de leitura e da escrita, nas escolas ou noutros contextos de ensino e de aprendizagem nesta área específica, ainda não têm o resultado desejável. A título de exemplo, em Moçambique, foi uma consternação geral ver, num dos canais de televisão, meninos que estando no fim do ensino primário do $1^{\mathrm{o}}$ grau ( $5^{\mathrm{a}}$ classe) não sabiam escrever direito o seu próprio nome. Situação similar é descrita no texto deste número, cujo título é "Ler e escrever um direito de todos", e que chama a atenção para a necessidade de uma identificação e aplicação de alternativas pedagógicas para eficaz transmissão de conhecimentos ligados à leitura e à escrita - um direito universal. É que nesta sociedade em mudança, como se lê no texto "Educar para outro mundo possível diante dos desafios colocados pela globalização capitalista" se torna também um desafio "construir um outro perfil docente, uma outra imagem, de um profissional que tem que lidar com questões metodológicas, com as teorias e obras pedagógicas não como um fim 
em si mesmas, mas, sobretudo, como mediação da relação dialógica que se estabelece com os alunos".

Para terminar, as abordagens deste gênero, não só no setor educacional, tornam os cidadãos capazes de iniciativas e de se adaptarem, rapidamente, não só às transformações sociais, mas também às demandas profissionais, capazes, por isso, de, cotidianamente, assumirem uma nova identidade. É o que falta, por exemplo, em Cabo Verde, onde se faz sentir a ausência de políticas efetivas em relação às pessoas portadoras de deficiência e uma falta de divulgação de direitos legislados, como é descrito no texto intitulado "Inclusão social de pessoas com deficiência em Cabo Verde - África".

\section{Domingos Buque}

Docente da Universidade Eduardo Mondlane

\section{Como citar:}

BUQUE, Domingos. Apresentação. Revista Moçambrás: acolhendo a alfabetização nos países de língua portuguesa, São Paulo, ano 1, n. 2, 2007. Disponível em: <http://www.mocambras.org>. Publicado em: março 2007 